\title{
Poema sem razão
}

\section{Cilaine Alves Cunha}

Resumo: Em Álvares de Azevedo e Bernardo Guimarães, a estilização do ócio e da preguiça ora se aproxima da cultura grega que os tomava por fonte da liberdade e da sabedoria, ora metaforiza um cansaço com temas e princípios estéticos que circulavam durante o romantismo brasileiro. Palavras-chave: ócio, preguiça, romantismo brasileiro.

Abstract: In Álvares de Azevedo and Bernardo Guimarães writings, the stylization of idleness and sloth sometimes approaches the Greek culture, which took them by a source of freedom and wisdom, and sometimes metaphorizes weariness with themes and aesthetic principles that circulated during the Brazilian Romanticism. Keywords: idleness, sloth, Brazilian Romanticism. 


\section{Quietude vegetativa}

Recorrente na prática literária da primeira metade do século XIX, o tema do ócio e da preguiça alcança um considerável número de poesias de Álvares de Azevedo e de Bernardo Guimarães, atravessando as distintas partes de suas respectivas obras lírica e satírica. Em Lira dos vinte anos, o primeiro desses poetas compreende algumas atividades do ócio como requisitos essenciais a uma vida ditosa. Fundamentando uma recusa do ritmo da vida administrada pelo tempo mecânico do relógio, o culto do ócio fornece-lhe ainda bases para uma reflexão sobre a subjetividade, seu próprio sistema poético e a estética romântica. ${ }^{1}$

No poema Anima mea, o sujeito lírico almeja alcançar um estado favorável à conquista da impossível unidade de sua alma. Num descanso contemplativo, exalta a cessação plena das atividades físicas e sensoriais como um ideal de vida do poeta, enquanto representa os elementos naturais com análoga força distensional. A produção de uma analogia entre a mórbida quietude do sujeito e de sua amada com o sossego despertado pela natureza é condição essencial à apreensão da ideia poética: "Ah! vem minha Ilná: sei harmonias/ Que a noite ensina ao violão saudoso/ E que a lua do mar influi na mente". ${ }^{2} \mathrm{O}$ sujeito lírico pressupõe que a quietude silenciosa da tarde e o repouso do gênio, sua distensão muscular que assim comunga com o cosmos, favorecerão o domínio dos "mistérios da floresta" e, assim, facultarão o acesso ao conhecimento de si e do mundo. De posse dele, o poeta pode equiparar-se ao criador do Universo, apreender, quem sabe, o fiat lux e gestar a arte. ${ }^{3}$

Já entre os poemas de Bernardo Guimarães que abordam o ócio, "Hino do prazer" encaixa-se em "Inspirações da tarde", volume de poemas acrescentados à segunda edição (1858) de Cantos da solidão, livro de início da carreira do autor em que predomi-

Como parte de sua dedicação ao assunto, Álvares de Azevedo traduziu como "Relógios e beijos" um poema de Heine que credita a invenção do relógio a um homem triste e solitário. Para suportar uma noite de rigoroso inverno, o inventor da cronologia entretém-se com o chiado dos camundongos e com o ruído das bicadas do cupim. Ao imergir em pensamentos despertados pela percepção dos animais, o homem deixa ver a baixa qualidade de sua vida interior.

2 A edição de Álvares de Azevedo aqui consultada é: Poesias completas. Ed. Péricles Eugênio da Silva Ramos/ Org. Iumna Maria Simon. Campinas/São Paulo: Unicamp/Imprensa Oficial, 2002.

Sobre a relação entre o sono e a aquisição do conhecimento entre os românticos, cf. BÉGUIM, Albert. L'âme romantique et le rêve. Paris: Libraire José Corti, p. 67-84.

Teresa revista de Literatura Brasileira [12|13]; São Paulo, p. 430-454, 2013 • 431 
na um discurso grave e por vezes edificante. ${ }^{4}$ Nele, um representante típico da vida dissoluta, o Filho dos Prazeres, dirige-se à juventude boêmia e letrada, aconselhando máximas para uma vida feliz baseadas no epicurismo. Sob o mote de que é doce viver sem contar as horas, o primeiro dos três cantos do poema saúda a vida dedicada à libertinagem, elegendo festins, banquetes, a conversação, a amizade, o canto e a orgia sexual por companheiros indispensáveis. Avaliando que o tempo empregado nessas atividades, livre de cronometragem, é superior àquele dedicado a vigiar "avaros cofres", o sujeito discursivo recusa a ação racionalmente orientada para o trabalho e a acumulação, prevendo que estes deterioram a consciência. A passagem em questão atualiza a tradicional condenação da cobiça, vinculando-a à fome e à exclusão social:

Antes assim, do que passar os dias,

- Qual feroz caimã, guardando o ninho,

Inquieto a vigiar avaros cofres,

Onde a cobiça aferrolhou tesouros

Colhidos entre as lágrimas do órfão

E as ânsias do faminto.

No canto seguinte, no entanto, a voz discursiva solicita aos convivas que deponham as taças e suspendam a vida dedicada à boêmia, elegendo novos fatores para a conquista da felicidade. A pressuposição de que o descanso e o silêncio, temperados com algumas gotas de melancolia, também banqueteiam o espírito procura valorizar a quietude sensível e impor limites aos excessos de uma vida dedicada à libertinagem. O segundo canto abre-se com uma epígrafe de Lamartine - "Je veux rever, et non pleurer!" -, desenvolvendo-se como uma reposição do culto da melancolia, convencionalmente codificado, segundo se sabe, como fonte da meditação, da conquista da sabedoria e do desfrute do belo. Despertada pela solidão das campinas, à sombra da mangueira ou em plácido remanso, a nostalgia pode também fornecer as condições propícias à inspiração de "aéreos cantos".

“Hino do prazer" persegue, à maneira epicurista, a justa medida em cada um dos estados e estilos de vida tidos por essenciais à aquisição do prazer. Ao se apoiar na epígrafe de Lamartine, poeta exemplar da elegia romântica, o Filho dos Prazeres procura legitimidade para desaconselhar os excessos da incursão na melancolia,

4 A edição aqui consultada dessa obra é GUIMARÃES, Bernardo. Poesias completas de. Org. Alphonsus de Guimarães Filho. Rio de Janeiro: Ministério da Educação e Cultura; Instituto Nacional do Livro, 1959. 
supondo com o poeta francês que o sonho é preferível ao lamento. A temperança deve guiar o gosto pela melancolia, a ser cultivada na medida em que a fruição da natureza a desencadeie, e a criação poética exija. A prudente rejeição da intensificação da tristeza à dor extrema deriva, de um lado, do cuidado para não ferir o princípio que rege o poema. Mas também se assenta na recusa de códigos religiosos austeros que, antevendo a era do Juízo Final, prescrevem um ascetismo intramundano como norma de uma vida que se prepara para o além. O Filho dos Prazeres descrê, no entanto, da imortalidade da alma, com seus correlativos de salvação ou danação eterna. Incorrendo em niilismo, postula que a vida desemboca antes no não-ser quando tudo se revolve no nada: "A campa! - Eis a barreira inexorável,/ Que nosso ser inteiro devorando/ Ao nada restitui o que é do nada!...”.

“Hino do prazer" repõe o idílio tradicional à luz do contexto romântico, situando a vida campestre não em uma paisagem domesticada, como no século anterior. Instala-a em um mítico espaço natural, anterior à história, ${ }^{5}$ espécie de jardim dos prazeres em que predomina um isolamento completo do mundo civilizado. Nesse momento, o bon vivant elege o entardecer e o leito recoberto de musgo e flores como hora e lugar propícios para concretizar a posse amorosa. Na hora vespertina, a estilização da prática sexual no ambiente natural aproxima a natureza rústica da liberdade sexual, fonte última do prazer de viver. Quase ao final do poema, a figura feminina gradualmente se desfaz de cada uma das peças de sua vestimenta até deixar entrever os seios no jogo de luz e sombra naturais. A atividade sexual desemboca no êxtase do sujeito amoroso que então se vê afetivamente fundido à natureza, como figura a seguinte apóstrofe altissonante dirigida a ela:

Eu sou feliz! - cantai minha ventura,

Auras da solidão, aves e bosque;

Astros do céu, sorride a meus amores,

Flores da terra, derramai perfumes

Em torno deste leito, em que adormece

Entre os risos de amor o mais ditoso

Dos seres do universo! [...] 
Destoando das orientações da personagem, entretanto, o poema se fecha com uma máxima exemplar, quando o Filho dos Prazeres cai abruptamente em completo abatimento. Desde então, a voz do bon vivant desaparece, substituída pela intromissão de uma onisciência letrada que, num tom doutoral, extrai daí a lição que arremata o poema, pressupondo ao final um conflito entre cristianismo, de um lado, e epicurismo e amor livre, de outro, afirmando aquele contra estes. Ao procurar gozar a vida sem observar as "lições severas" que se podem extrair da inevitabilidade da morte, a personagem alcança, sob a ótica onisciente, um gozo intenso, mas temporal e efêmero, perdendo a oportunidade de se precaver contra as desilusões que arrastam para a morte. No contraexemplo fornecido pela personagem, a voz onisciente replica a sua consciência da finitude, contrapondo-lhe a presença sempre-eterna da força divina que a todos golpeia.

Por outro lado, "Hino do prazer" dedica três longos cantos para celebrar, em chave lírica, o prazer como norma de vida e uma única estrofe para condená-lo, destacando apenas brevemente os castigos divinos que aguardariam os supostos incautos. No conjunto do poema predominam as lições mundanas. Considerando a gargalhada posterior de Bernardo Guimarães para com as ideologias que procuravam controlar a cultura oitocentista, a concisão e a rapidez na exploração de uma lírica edificante podem ser indicativas da pouca convicção do autor diante de gêneros didáticos. $\mathrm{O}$ traço mais ingênuo de "Hino do prazer" reside no intuito voltado para edificar e confirmar a ideologia cristã.

\section{A cultura do ócio}

No século XIX, a reposição do ócio pela literatura ocorre quando o relógio já deixara de ser índice de riqueza, tornando-se objeto útil de regulação do modo de produção industrial. No interior das fábricas da Revolução Industrial, o ritmo do trabalho do artesão e do camponês, descontínuo e alternado com outras tarefas, submete-se aos poucos a uma rigorosa sincronia e automação, passando a variar entre dez, catorze ou mais horas. Para impor e sedimentar na cultura o ritmo do novo modo de produção, o capitalismo industrial empreendeu uma fervorosa campanha contrária às diversas festividades em homenagem aos dias santos. ${ }^{6}$ Com o apoio de certo segmento da

Cf. THOMPSON, E. P. Costumes em comum. Estudos sobre a cultura popular tradicional. São Paulo: Companhia das Letras, p. 290. 
Ilustração favorável à modernização do aparelho do Estado, ao controle do tempo livre dos trabalhadores e à preservação do ócio como prerrogativa dos membros da nobreza e do filósofo, ${ }^{7}$ essa campanha aos poucos veio transformando em negócio atividades recreativas até então praticadas comunitariamente, como jogos, competições e festivais. Paulatinamente o século xıx enterra a cultura do ócio. ${ }^{8}$

A reatualização artística do tema no período é também parte de um sistema que concentrou em poucos anos as contradições que vieram se perpetuando. ${ }^{9}$ Entre estas, o advento da ciência moderna e a ascensão do capitalismo por todas as atividades da vida cotidiana e pelas relações humanas em geral inverteram a hierarquia tradicional que valorizou o ócio (otium) com fim em si e modo de vida livre. O moderno sistema econômico degenerou a importância que a cultura grega clássica destinava à vida contemplativa e à política em detrimento do labor e do negócio (neg-otium). Reforçando a condenação cristã da preguiça, liberou o trabalho de sua antiga limitação ao reino da necessidade, e o labor e o negócio de sua restrição ao ambiente doméstico, sacralizando a ética burguesa do trabalho como norma da vida. ${ }^{10}$ Consideradas pela Bíblia pecado capital e penitência divina pela perda do paraíso, a opressão imposta pelo mundo do trabalho e a acumulação tornaram-se virtude desde então: "Trabalhar é ganhar para poupar e investir para que se possa trabalhar mais e investir mais". Na Grécia antiga, o ócio, privilégio do cidadão ateniense, é garantido, como se sabe, à custa dos escravos. Ele não se confunde com a atual noção de tempo livre, nem de lazer, mercantilizados pela indústria cultural. Em Aristóteles, a finalidade do descanso e da diversão assenta-se na necessidade de recuperar forças físicas para mais trabalho, dele não se desvinculando. Apenas o ócio, com fim em si, pode ser fonte da liberdade e da felicidade. ${ }^{12}$ Assentada no princípio de que a necessidade suprime

Sobre a vertente funcional da llustração em meio à qual figuram Voltaire, Diderot, entre outros, cf. ROUANET, Sergio Paulo. Ociosidade e ócio no pensamento da Ilustração. In: Elogio à preguiça. São Paulo: Edições Sesc, 2012, p. 166-174.

8

Cf. GRAZIA, Sebastian de. Tiempo, trabajo y ocio. Trad. Consuelo Vazquez de Paga. Madrid: Editorial Tecnos, 1966, p. 49.

9 Para uma abordagem dessas contradições, cf. MATOS, Olgária. Adivinhas do tempo: êxtase e revolução. São Paulo: Hucitec, 2008, p. 9.

10 Cf. ARENDT, Hannah. A condição humana. Trad. Roberto Raposo. Rio de Janeiro: Forense Universitária/ Salamandra; São Paulo: Edusp, 1981, p. 37-46.

11 CHAUÍ, Marilena. Introdução a LAFARGUE, Paul. O direito à preguiça. Trad. J. Teixeira Coelho. São Paulo: Hucitec/UNESP, 1998, p. 14. 
a autonomia, a definição aristotélica considera que o labor dos escravos é também coagido pela necessidade de tirania do déspota que assim também não é livre. Do reino da liberdade torna-se ainda proscrita a vida do mercador que, deixando de desfrutar do prazer da conversação, da amizade e do conhecimento, revela-se, para continuar dizendo com Walter Benjamin, ${ }^{13}$ uma alma vulgar que, aspirando a bens terrenos que privam o tempo do ócio, deforma seu espírito e corpo. O mundo do trabalho interdita o acesso à sabedoria e leva os que a ele se entregam a seguir o destino dos escravos. Como atividades do ócio que proporcionam felicidade, não a mera sensação agradável, a música e a contemplação ocasionam um prazer livre e desinteressado de qualquer outro fim, podendo favorecer o cultivo da mente e o acesso à verdade do Universo. Essas atividades poderiam preparar os homens para a vida ativa na política, na medida em que, libertando-os das perturbações da alma e das distorções da percepção criadas pela necessidade, contribuiriam para que reconhecessem o bom e o verdadeiro. ${ }^{14}$

Já desde a decadência da cidade-estado grega, no entanto, emerge, nos termos de Hannah Arendt, a superioridade da vida contemplativa sobre a vida ativa na polis, num fenômeno favorecido em seguida pela disseminação do epicurismo e pelo cristianismo. Em Epicuro, a abstenção do movimento físico e o afastamento de ações e desejos que causam desassossego (ascolia) definem a vida do filósofo. A absoluta quietude do corpo e da alma, a cessação de todo tipo de pensamento, raciocínio e discurso, torna-se pré-requisito para que a verdade se revele. ${ }^{15} \mathrm{~A}$ vida dedicada à filosofia, ao conhecimento de si e do mundo, e cuja fonte se assenta nas sensações, alimenta a liberdade. Entendendo que o prazer é princípio e termo final da vida, Epicuro aconselha um prudente discernimento entre as regras úteis ou prejudiciais à felicidade. Nele a satisfação indiferenciada das necessidades é também fonte de desprazer. O epicurismo elabora, assim, um prazer sobretudo negativo, cujo princípio maior é "evitar o desprazer do que desejar o prazer. A verdade pela qual o prazer deve ser medido consiste em fugir do conflito com a ordem estabelecida. O objetivo é a tranquilidade da alma do sábio" ${ }^{16}$ Vetando a participação na vida pública e na

BENJAMIM, Walter. Arquivo m: "Ócio e ociosidade". In: Passagens. Trad. e Irene Aron e Cleonice Paes Barreto. São Paulo: Imprensa Oficial, 2007, p. 839.

14 Cf. GRAZIA, Sebastian de. Tiempo, trabajo y ocio, op. cit., p. 22. 
política, Epicuro propõe que o prazer estável e em repouso favorece a ausência de perturbações da alma (ataraxia) e de sofrimento (aponia). Contrários à natureza, o pesar pelas dores ou a ânsia por prazeres dissolutos devem ser evitados quando inconvenientes. ${ }^{17}$

Com o cristianismo, o engajamento nos assuntos da polis, antes livremente escolhido pelo senhor, torna-se necessidade, perde espaço para a vida contemplativa e deixa de participar do reino da liberdade:

O primado da contemplação sobre a atividade baseia-se na convicção de que nenhum trabalho das mãos humanas pode igualar em beleza e verdade ao kosmos físico, que revolve em torno de si mesmo, em imutável eternidade, sem qualquer interferência ou assistência externa, seja humana, seja divina. ${ }^{18}$

Um dos responsáveis pela atualização do epicurismo no século xIX, Friedrich Schlegel, em "Idílio sobre o ócio", contribui para uma revisão na doutrina antiga, ao destacar, na contemplação, a possibilidade não apenas de conquista da sabedoria e de conhecimento da alma. Desde Rousseau, trata-se de valorizar no ócio meditativo a possibilidade de conhecimento do indivíduo em estado de natureza, ${ }^{19}$ do conhecimento da intimidade do coração, de recuperação das forças naturais do ser humano, dos processos da mente e do movimento das percepções sensoriais ${ }^{20}$ o que poderia libertar o indivíduo da opressão social e das deformações de sua alma. Concebendo que o ócio aristocrático se assenta na opulência, num excesso de atividade e na necessidade, Rousseau privilegia o ócio solitário como condição para que o sujeito se autocontemple e se circunscreva longe da ordem e da convenção sistêmica que anulam a liberdade. ${ }^{21}$ Atividade como caminhada, herborização desinteressada e passeios de barco são momentos propícios para o devaneio criativo e para a emancipação. “Idílio sobre o ócio" é parte de Lucinde (1799), a prosa de ficção em que Schlegel, forjando uma radical fragmentação do conjunto, funde filosofia e arte como resultado de uma teoria do romance moderno que pressupõe a mistura entre os diversos assuntos

Cf. EPICURO. Carta a Meneceo. In: Los filósofos antigos: selección de textos. Fernandez, S. I., Clemente (Compilador). Madrid: La Editorial Catolica S. A, 1974, p. 471.

18 ARENDT, Hannah. A condição humana, op. cit., p. 25.

19 Cf. ROUANET, Sergio Paulo. Ociosidade e ócio no pensamento da llustração. In: Elogio à preguiça, op. cit., p. 170.

20 ARENDT, Hannah. A condição humana, op. cit., p. 50.

21 ROUSSEAU, Jean-Jacques. Os devaneios do caminhante solitário. Trad. Júlia da Rosa Simões. Porto Alegre: L\&PM, 2012, p. 16. 
e formas artísticas distintas. Em Lucinde, o ócio inscreve-se no interior de um projeto de aperfeiçoamento do sujeito como condição do aprimoramento estético e ético da humanidade. Nesse projeto, a formação do sujeito deve considerar a emancipação da mulher e a libertação do homem burguês das deformações impostas pelo ascetismo moral, o racionalismo e o utilitarismo. Ainda que reafirme a eternidade do amor que ligaria os membros do par amoroso, Schlegel valoriza o cultivo do sentimento da carne ao lado do da vida espiritual, de sorte que homem e mulher deveriam predispor-se a outras experiências sexuais se quisessem enriquecer a vida a dois. A garantia plena da liberdade sexual não exclui a inversão dos papéis feminino e masculino, desembocando, em Lucinde, na apologia do pan-erotismo. Num momento em que a ideologia burguesa do trabalho empreende a companha que acarretou a divisão entre trabalho e tempo livre e a intensificação do controle do corpo e da sexualidade - inclusive os do filósofo - para os fins da acumulação, a reação de Schlegel espera que o ócio e o amor livre alimentem a fantasia e deem forma à arte. Com isso, seria possível manter o gozo da existência como mola propulsora de uma nova humanidade.

A certa altura do "Idílio sobre o ócio", Julius, o narrador, recupera um momento do passado, quando, à beira de um regato, observava o fluxo de suas águas. A passagem produz uma analogia entre a contemplação da corrente das águas do riacho com a produção de ideias pelo pensamento. Impelida pelo sossego da natureza e pelo espetáculo da água, a reflexão do narrador põe-se em movimento e desperta a sua consciência para a importância do ócio na vida humana. Como produto da quietude, Julius vê-se então assaltado por duas fantasias antagônicas. Em uma delas, visualiza homens que, sem jamais terem sonhado ou experimentado a vida em sua plenitude, subtraíram as horas do sono para disseminar o trabalho sem trégua e o progresso indefinido. Na parábola que encerra o ensaio, o narrador torna-se invisível no interior de um teatro, onde assiste ao trabalho infindável de Prometeu: atado a uma corrente, ele confecciona figuras humanas desprovidas de vida interior. Nessa alegoria do adestramento do corpo e das consciências pelo modo de produção industrial, Prometeu arremessa à plateia cada ser vivo quando pronto que então se transforma, ao lado de outros já previamente fabricados, em massa uniforme e indistinta. Em outra metáfora, Prometeu, ao roubar a luz, condenou-nos ao mundo do trabalho, mas permitiu que apenas um entre os homens detivesse essa luz e, assim, passasse a moldar os demais. Anjos da morte, o zelo e a utilidade são invenções do Iluminismo e da ciência moderna que, disseminando o racionalismo, mantêm a mente em constante atividade. Quando em repouso, a consciência opera no vazio, amesquinha-se e passa a controlar umas às outras, ao contrário do ocioso que, se dedicando ao cultivo da mente e ao amor, forma e desenvolve o seu eu. 


\section{Variações do ócio em Álvares de Azevedo}

Por eleger a contradição como figura central de sua obra, e a ironia e a autoironia como procedimentos fundamentais de seu modo de criação, Álvares de Azevedo estabeleceu, como se sabe, uma contraposição entre as duas partes de Lira dos vinte anos. Para tanto, introduziu um diálogo crítico de poemas da segunda com outros da primeira parte desse livro, de tal modo que temas e ideais antes postulados ganham em seguida um destino diferente ou antagônico. Nesse sentido, a parte satírica da Lira dos vinte anos revisa a anterior concepção e estilização do tema do ócio, que ora pode receber uma orientação semântica diferente daquela concebida em Anima mea, ora sofrer uma derrisão, resultando em binomia, como preferia o poeta.

Anima mea insere-se na primeira parte da obra lírica de Azevedo, de cunho mais ingênuo se comparado ao restante do livro. Na seção satírica da segunda parte dessa obra lírica, o poema "A minha esteira" produz um afastamento do tom grave e sombrio de Anima mea, introduzindo uma sutil ironia com uma das atividades do ócio. Para distender o elogio à sua esteira, o sujeito lírico hiperboliza o ato de nela repousar. Na larga duração temporal de sua mocidade e nas noites de luar, enquanto canta estirado em seu leito ele aspira a sombra do vale e o perfume da natureza, ao som do canto dos pássaros e do murmúrio das folhas da mangueira. A cena se constrói, assim, por meio de uma sobrecarga sinestésica cujo efeito é o da completa distensão. Desenvolvido em cinco quadras, a segunda e a terceira destacam a presença da amada cantarolante ao lado do jovem poeta que, em que pese a companhia, reitera, ainda assim, a sua declaração de amor à esteira, deslocando o objeto de suas preferências amorosas da mulher para o leito: "Nem o árabe Califa, adormecendo/ Nos braços voluptuosos da estrangeira,/ Foi do amor da Sultana mais ditoso/ Que o poeta que sonha em sua esteira".

Ao comparar o poeta sonhando ao lado de sua amada com Califa adormecendo em meio à volúpia de sua Sultana, Azevedo também aproxima a suposta frieza sexual do árabe à indiferença do poeta com um momento propício para concretizar a posse amorosa. A brincadeira não deixa de debochar do ascetismo sexual do jovem poeta estilizado em Anima mea e ao longo de "A minha esteira", mas ao mesmo tempo de ressaltar no devaneio a fonte maior da felicidade.

$\mathbf{O}$ cultivo intransigente do ócio e a opção por uma vida esteticamente contemplativa levam à fusão do poeta com a natureza, num procedimento favorecido pela repetição do seguinte dístico no início da primeira e da última quadra, o que fecha o poema em círculo: "Aqui do vale respirando a sombra/ Passo cantando a 
mocidade inteira". O envolvimento do sujeito pelo espaço natural, durante a sua juventude, faz predominar o tempo perceptível pelos sentidos, não pela mensuração mecânica. A comunhão do poeta com a natureza durante essa hiperbólica duração encena a concepção rousseauniana de felicidade como um estado sólido e contínuo que, procurando tornar permanente o instante do deleite com a própria existência, desconhece "o tempo que passou e o que pode vir". Anulando o próprio tempo, constrói uma duração "sem duração, sem nenhum sinal de sucessão, sem nenhum outro sentimento de privação ou de deleite, de prazer ou de dor, de desejo ou temor". ${ }^{22}$ Para inserir o sujeito na vida plena da natureza, com valor em si, e tornar constante o instante fugidio da eterna juventude e felicidade, o sujeito prescinde das coisas externas e despoja-se de qualquer "afeto, paixões e impressões sensuais e terrenas" ${ }^{23}$ que causem desassossego. Ao final, a vida devotada à ataraxia desemboca numa morte simbólica em que amor, sonho e imaginação reinam absolutamente: "Vivo de amores; morrerei sonhando".

Ao procurar manter, em "A minha esteira", um permanente afastamento dos dissabores como condição de uma vida dedicada à fantasia artística, Álvares de Azevedo faz coro, por um lado, com a inversão na hierarquia dos campos do saber empreendida pelo romantismo que, sobrevalorizando a arte, disputa com a filosofia o domínio do conhecimento. Por outro, sua incessante criação de esferas transcendentes, em que reinam o sono, o sonho, a morte simbólica e a imaginação, prevê uma reação à evidência de que a consciência é de início uma tábula rasa na qual a cultura imprime continuamente camadas de experiência e de conhecimento até gradativamente formar o eu. Recusando os ditames da cultura na formação da consciência e privilegiando aquelas esferas, o poeta procura deslocar-se para um tempo primeiro, a uma hora zero de sua consciência quando a tradição familiar e cultural, as ideologias, valores e normas de conduta ainda não teriam imprimido as suas marcas na percepção, antes que esses supostos desvios tornem ainda mais impossível o conhecimento do eu interior. Nessa narcísica regressão secundária, o sono e o sonho são condições para que a interioridade do sujeito se dê a ver, livre de todo condicionamento externo. Esse recuo a um tempo mítico da consciência poderia proporcionar o acesso ao suposto núcleo coeso de sua própria alma. A morte em Álvares de Azevedo metaforiza o fim do peso da tradição familiar e cultural sobre a formação da consciência individual, como se o indivíduo pudesse ser um Kaspar Hauser que se autodeterminasse livre-

ROUSSEAU, Jean-Jacques. Os devaneios do caminhante solitário, op. cit., p. 70.

23 Idem

440 • CUNHA, Cilaine Alves. Poema sem razão 
mente, de preferência sem as ingerências também das pulsões, antes condicionado pelo impulso lúdico. O elogio da vida em estado de natureza corre paralelo ao esforço para conhecer esse núcleo original da subjetividade, o qual, logo em seguida, Freud chamará de inconsciente.

Diante de um mundo que se encaminhava para a generalização do primado econômico, o poeta romântico reage à uniformização da experiência e ao tédio gerado pelo primado do homo economicus, ou puro cálculo ou instrumento da acumulação, e ao desencantamento do mundo. A valorização romântica do sono, do sonho, da fantasia e da imaginação figura ainda um lugar e um tempo exóticos pré-capitalistas, aquém ou além do valor econômico e da consciência administrada. ${ }^{24}$

No momento satírico de sua obra, Álvares de Azevedo acrescenta a renúncia a bens materiais e os prazeres do corpo aos demais fundamentos do ócio, da fantasia artística e da felicidade. No poema "Boêmios", Puff propõe que a contemplação é condição para liberar e ativar a imaginação. Além disso, a poesia também "dorme dentro do vinho: Os bons poetas/ Para ser imortais, beberam muito". Com altivez, pressupõe que o autêntico poeta deve cultivar a pobreza e se entregar à indolência, à boêmia e à arte.

Outro poema de estilo prosaico, "Vagabundo", desenvolve-se como solilóquio enunciado por um poeta mascarado de miserável feliz que traça um elogio da vagabundagem. Aparentemente, os versos se organizam no interior da quadra sem obedecer a uma ordenação lógico-conceitual. Não sem exceção, o modo de associá-los procura a simplicidade e a espontaneidade, ora vinculando os versos de dois em dois, ora em uma sucessão de linhas autônomas que encadeiam descrições e mininarrativas condensadas. De verso a verso o vagabundo descreve estados interiores e relata ações que compõem gradativamente o perfil e o modus vivendi de um mendigo dotado de uma sabedoria ímpar do bem viver.

Em que pese, porém, a aparente simplicidade, oposições e contradições compõem o eixo estruturante de "Vagabundo". A antítese e o paradoxo condicionam a seleção e a combinação dos vocábulos no interior dos versos, destes no interior das quadras e no conjunto do poema. Aproximando opostos, o vagabundo se autodescreve por meio de adjetivos e ações que ou se completam, ou se negam mutuamente. Como sátira irônica que é, faz predominar um tom jovial e lúdico que procura afirmar a liberdade proporcionada por uma vida livre e esteticamente condicionada. 
Em seu tempo livre o miserável dedica as horas diurnas à quietude e ao descanso, $\mathrm{e}$ o tempo noturno à vida ativa, caracterizada, no entanto, por ações absolutamente gratuitas, como namorar estrelas. No verso inicial, "Eu durmo e vivo ao sol como um cigano", a equiparação entre o vagabundo e o cigano realiza a primeira inversão dos preconceitos sociais. Ao longo da cultura ocidental, a etnia dos ciganos tendeu a ser estilizada no grau mais baixo da hierarquia artística, moral e social. Mas no poema de Azevedo, a comparação é parte da adesão à mistura estilística empreendida pelo romantismo, que procura dignificar elementos até então considerados vulgares e, na contramão, jogar heróis tidos por nobres ao rés do chão.

O mendigo expõe, com altissonante orgulho, seus andrajos, numa estratégia metonímica que reafirma a sua opcional miséria. A segunda estrofe opõe a suposta pobreza interior do homem de posses à qualidade afetiva e artística da psicologia do miserável, reproduzindo o contraste entre bens materiais e espirituais. Livre das preocupações geradas pelo mundo do dinheiro, o vagabundo pode dedicar-se aos amores e às serenatas à lua. A pintura da miséria como uma venturosa fortuna procura enobrecer o tipo tradicionalmente cômico.

Prosseguindo no elogio do pobre espiritualmente rico, a terceira estrofe anuncia, no entanto, a primeira tensão dramática no interior do poema que, a partir da sexta quadra, forjará o vínculo entre humor e seriedade irônica dispensada aos valores e ideologias que organizam o mundo da cultura. Na estrofe, o anti-herói procura colar a sua imagem à figura do indivíduo despojado que se crê livre da inveja dos bailes fascinantes: "Não invejo ninguém, nem ouço a raiva/ Nas cavernas do peito, sufocante,/ Quando à noite na treva em mim se entornam/ Os reflexos do baile fascinante". Ao asseverar que não inveja bailes suntuosos, o anti-herói procura colar a sua imagem a um caráter magnânimo. Nos versos acima, os enjambements, os modificadores e o violento hipérbato do verso final distanciam o termo "raiva" de seu complemento ("reflexos do baile fascinante"), disfarçando o sentimento negativo em magnanimidade. Os reflexos luminosos do baile fascinante entornam-se sobre o lugar de treva ocupado pelo mendigo que, expiando-o, sente, no entanto, seu peito sufocando. Assim, embora se acredite livre da inveja, a raiva e a opressão do peito são efetivos, o que transforma o desdém em denegação e deixa ver o sentimento de exclusão e o ressentimento social.

O poema também relata casos plurais de amor como fonte da felicidade. Tomando o autor pela obra, o afoito abrasamento da criada por um soneto metaforiza a sua atração sexual pelo vadio. Sua audácia amorosa opõe-se à falsa timidez da recatada donzela à janela. Ao contrapor os pares criada e donzela, ousadia e falso recato, o 
sujeito pretende ilustrar, em quantidade e intensidade, o vigor de sua sexualidade, denunciando, assim, o vaidoso autoelogio desse Don Juan desprovido de fortuna. A afirmação da masculinidade pelo vagabundo realiza-se também em sua petição de que a pulsão sexual seja natural em um distinto jovem, na frase "Sou garboso e rapaz..... Em conjunto, o falso monólogo dessas duas estrofes lembra uma conversação entre rapazes que empreendem uma disputa para definir o grau de sua virilidade. A argumentação do jovem esforça-se por convencer o leitor acerca de sua suposta potência sexual, o que se manifesta também em "Desconfio que a moça me namora". Aí, a atração da donzela pelo rapaz realiza-se como suposição. Em que pese, contudo, a hipótese, o herói já a computa no rol de suas admiradoras.

A partir da sexta estrofe, o jogo de oposições concentra-se na encenação e inversão dos códigos que regulam a vida burguesa, o que desemboca na mistura do humor com a reflexão crítica sobre certas práticas discursivas predominantes. Além disso, o modo de organizar os versos no interior das estrofes seis a nove mimetiza a perspectiva do andarilho. $\mathrm{O}$ ritmo de suas andanças ao léu determina o encadeamento aleatório de versos, compondo a irregularidade e a variedade temática dessas quatro estrofes. Azevedo procura imitar os pensamentos gratuitos que emergem casualmente na mente do andarilho enquanto ele vaga pela cidade.

Na sexta estrofe, a sequência das ações que se dão a ver são: morar na rua, passear a gosto, dormir sem temores, beber vinho como um poeta-rei e sonhar com os amores. Como as demais, são ações que carecem de qualquer utilidade, nem se prendem a necessidade alguma, determinando-se, antes, pelo ritmo da vida ao léu. Mas são também ações que contrariam valores tidos por sagrados, como a autopreservação, o bem-estar e o sucesso profissional, invertendo-os em estima e consideração. A notação dessas distintas ações valoriza, assim, o modo de vida determinado pela experiência múltipla de quem vive longe da disciplina e da monotonia do mundo do trabalho.

Reiterando o orgulho de sua miséria, o vadio pode assim transportar o luxo, o conforto e a suntuosidade de um palácio para a sua moradia de rua. Nesse castelo ao ar livre, o degrau das igrejas constitui-se como ponto fixo de parada, estimado como um trono. A motivação dessa entronização deve-se provavelmente ao desejo de afrontar o templo católico como instituição que condenou a preguiça a pecado capital. Analogamente, em tempo de intensa construção da nacionalidade e de propaganda nacionalista, o erradio amplifica a ideia de pátria, transferindo o seu sentimento de pertencimento dela para o vento, um símile da vida errante. Na escala de valores do excluído, o sentimento patriótico reduz-se à indiferença. No mesmo intuito voltado 
para contrariar um objeto consagrado em tópica pela tradição, a lua comumente suntuosa dos apaixonados e poetas perde valor para o marginalizado: a de sua preferência prima pela palidez. Fechando desabusadamente a sétima estrofe, o verso que elege a preguiça como objeto de amor afronta a sacralização do trabalho em virtude. A convicta vida ociosa e errante favorece ainda uma prática artística realizada em diferentes domínios: cantor de serenatas, o anti-herói também se dedica à poesia e à pintura, empregando, para tanto, materiais paupérrimos e de fácil aquisição. Em vez de papel, utiliza paredes como suporte de seus poemas; em vez de tintas e tela, carvão para pintar os muros da rua. O elogio da pobreza, tantas vezes reiterado, marca uma posição favorável à contemplação como um requisito indispensável a uma vida ditosa. Como na doutrina epicurista, o sujeito do discurso entende que a felicidade advém de uma vida que, embora não se contente com pouco, já que sente seu peito ofegante diante da vida luminosa dos salões, opta pelo mais fácil e que não aborrece o espírito. ${ }^{25}$

O fio condutor que orienta o poema leva-o a se estabilizar como um jogo paradoxal entre uma vida que acumula um tempo destinado à quietude, ao descanso e ao repouso, e outro tanto a uma gama ampla e intensa de outras atividades e experiências. A vida de ralé proporciona muitos banhos de sol, um sono tranquilo e intenso, o namoro das estrelas e da lua. Para transformar os banhos de sol em hábito, o poema reproduz o gosto pela prática na primeira e antepenúltima quadra ("abro meu peito ao sol"). O verbo dormir registra-se por três vezes, na primeira, na sexta e na oitava estrofe. A vida marcada pelo ritmo do acaso também favorece muito namoro, a degustação do vinho e a possibilidade de desenvolver o talento artístico em diferentes domínios da arte, na música, na poesia e na pintura. Gradativamente, o poema compõe uma relação de causa e consequência entre o ócio e a qualidade da vida vagamunda. $\mathrm{O}$ cultivo da indolência é então condição primeira de uma experiência dedicada ao deleite e à celebração da vida: "abro meu peito ao sol e durmo à lua". Mas ao final do poema, o jogo de antíteses desemboca em violenta contradição: "Não creio no diabo, nem nos santos.../ Rezo a Nossa Senhora, e sou vadio!". Trata-se aí da ironia por nadificação, em que tese e antítese se anulam e se afirmam com o propósito de atingir a ilogicidade, contrária ao Iluminismo e não menos ao cristianismo. Os versos declaram a descrença no dogma cristão e, simultaneamente, a adesão à prática religiosa da oração, constituindo o oximoro do incrédulo crente. Essa contradição permite ao poeta afirmar a sua liberdade quer para praticar o culto à Virgem, quer 
para se desvencilhar da filiação católica. Livre dela, o sujeito pode frequentar missas e transformar a igreja em ponto de repouso, moradia, encontro amoroso e convivência social, menos em templo de devoção religiosa. No ateu que reza a Nossa Senhora, a absoluta liberdade desse Lazzaroni para com os costumes e mentalidade de seu tempo permite-lhe provavelmente adotar uma prática da qual desacredita. Deixando o final em aberto, o poeta afirma o fragmentário e o inacabamento, recusando-se a fixar a univocidade semântica de seu poema, reagindo, assim, à sistematização das ideias. Uma ou outra interpretação pouco importa, pois o que se pretende é anular os polos estanques da verdade, jogar com os múltiplos sentidos da palavra e afirmar, com isso, a riqueza de uma vida determinada pelo acaso.

Por outro lado, aparentemente o engajamento político não encontra lastro na poesia de Álvares de Azevedo. No momento de composição desse poema, por volta de 1850, a proibição do tráfico negreiro, no Brasil, já acirrara as discussões dos círculos letrados sobre a substituição da mão de obra escrava pela do homem pobre e livre. Na prosa poética Meditação, Gonçalves Dias, por exemplo, condena a escravidão e credita o atraso do país à suposta improdutividade do indivíduo pobre e livre. $\mathrm{O}$ texto propõe alertar a consciência política sobre a utilidade de uma campanha que leve o homem livre e sem posses a optar ou pela vida ociosa entregue ao acaso e, assim, à precariedade, ou pela racionalidade do trabalho formal. No interior da obra de Gonçalves Dias, essa decisão coletiva teria de reconhecer que o esforço físico e o sofrimento causado pela tarefa de construção da infraestrutura do país seriam nobres e sublimes. Nesse cenário, o narrador de Meditação pretende introduzir no país a ética burguesa do trabalho e alterar o ritmo da vida, marcado pelo acaso, por outro determinado por uma produtividade pela qual os pobres livres deveriam sacrificar-se em nome do progresso e da civilização para os iguais.

Álvares de Azevedo, por sua vez, constrói um personagem que encarna o pobre em geral, seja de qual nação for, despossuído e livre. O humor irônico já se insinua na escolha do assunto do poema que se expande por meio da inversão da tópica da preguiça. Contrariamente à ideologia do trabalho em discussão nos círculos letrados, "Vagabundo" desenvolve a convicção de que a submissão ao mundo da necessidade empobrece, promovendo uma hiperbólica valorização do fracasso material e social e uma indiferença com o sucesso mundano. Como se partisse do provérbio de que mais vale quem Deus ajuda do que quem cedo madruga, o poema se constitui como negação da tese de que a pobreza honesta, conquistada no trabalho, dignifica.

Por fim, no recorrente princípio paradoxal com que Álvares de Azevedo organiza a relação interna de seus poemas e das partes de sua lira, se uma proposição e um 
procedimento estilístico se tornam de início norma e, em seguida, objeto de desconstrução, essa metamorfose ambulante fundamenta a crença de que a convenção da língua em uso e da linguagem artística congela a expressão da multiplicidade complexa da vida e da arte. Os significados que se inventam para elas podem ser perpetuamente revistos.

Nesse sentido, em momentos raros de sua obra Azevedo submete à derrisão a cultura do ócio e da boêmia. O poema "Lagartixa" não deixa de debochar da passividade contemplativa antes privilegiada, enquanto também desconstrói a figura da bela adormecida como símbolo do bom, do belo e do verdadeiro. A aproximação que o poema estabelece entre, de um lado, a luz do sol e o estiramento da lagartixa e, de outro, o brilho solar dos olhos da amada e a letargia entorpecente do poeta-lagartixa debocha da quietude sensível e do motivo do eterno-feminino, decretando com bom humor o esgotamento de uma e outro.

Numa passagem do canto III de O poema do frade, o narrador aborda os pressupostos artísticos dessa prosa-poética, discordando do libertino estilo de vida de sua personagem central, Jônatas, estranhando satiricamente que este, à maneira do segundo Álvares de Azevedo, imite a vida e a poesia supostamente hedonistas de Byron: "[...] Como o cantor de don Juan pensava/ Que é da vida o melhor a bebedeira.../ E a sua filosofia executava.../ Como Alfredo de Musset, a tanta asneira/ Acrescento porém... juro o que digo!/ Não se parece Jônatas comigo". ${ }^{26}$ Apresentando-se como um padre que resolvera assumir o celibato para escapar da devassidão, o narrador, enquanto observa a fumaça de seu charuto, lembra-se de situações de intenso prazer, como partilhar a companhia de uma bela voluptuosa, consumir vinho e distender-se pela relva da campina verde. Essas situações, no entanto, logo se reduzem a ilusões que negam os sonhos do poeta. Ao lado de cada um desses elementos, seu charuto - em cuja fumaça o segundo Álvares de Azevedo escuta o “canto d’alma” e figura o movimento de seu pensamento artístico - perde sua condição de objeto transferencial, esfria-se "além nas ondas", "como um cadáver arrojado ao mar". ${ }^{27} \mathrm{~A}$ imagem do gradativo apagamento do charuto boiando nas águas do mar torna-se, com isso, signo da perda das utopias juvenis do narrador, de sua atual concepção niilista de vida e de sua correspondente percepção acerca da morte de certo tipo de arte.

No soneto "Ao sol do meio-dia eu vi dormindo", o autor recupera mnemonicamente cenas do dia, quando o sujeito discursivo deparara-se com três tipos distintos

26 AZEVEDO, Álvares. O poema do frade. In: Poesias completas, op. cit., 315.

27 Idem, p. 329.

446 • CUNHA, Cilaine Alves. Poema sem razão 
que então realizavam alguma atividade típica da juventude boêmia: um marinheiro roncava expandindo os vapores do vinho, um espanhol esvaía-se na fumaça de seu cigarro feiticeiro, enquanto um careca pobretão tocava rabeca em uma esquina. Figuras populares como estas metaforizam, ao longo da obra azevediana, o último elo da cadeia de expansão e reprodutibilidade de algum tema ou princípio artístico quando estes, ao fim, sofrem um processo de entropia e perdem substância: “[... Vemos agora a poesia a rodo!/ Nem há nos botequins face vermelha,/ Amarelo caixeiro, alma de lodo,/ Nem Bocage d'esquina, vate imundo,/ que não se creia um Dante vagabundo". ${ }^{28}$ Nos versos, a figura do gênio maldito, misantropo e marginal perde valor. Num compromisso radical do autor com o princípio de originalidade, esses tipos populares encarnam o ponto culminante do movimento de rotinização de algum código artístico. Encerrando nesse momento um ciclo vital, a arte exigiria a partir de então a criação de novos elementos para se vivificar.

Em "Ao sol do meio-dia eu vi dormindo", atividades do ócio e da boêmia juvenil - como tocar rabeca, cultivar um sono etílico e fumar, emblemáticos, vale reiterar, do segundo Álvares de Azevedo - transformam-se em fonte do tédio. Diante da memória das cenas cotidianas em que sobressaem jovens entregues à indolência e à arte, o sujeito discursivo do soneto experimenta um enfado profundo e não mais delira: "Se morro de preguiça... o mais é seca!/ Desta vida o que mais vale um suspiro?”. No primeiro verso, o ócio avilta-se em preguiça e perde seu valor antes vital, agora concebido como fonte estéril da fantasia. Tudo indica que Álvares de Azevedo se encaminhava para criar um trinômio poético a partir da revisão do ideal de vida e dos parâmetros da boêmia artística e, com isso, desmontar o seu segundo sistema artístico.

\section{Variações da preguiça em Bernardo Guimarães}

Alguns poemas de Bernardo Guimarães também formam pares em que uma afirmação se duplica por negação, revisando, com humor irônico, a sua própria produção. ${ }^{29}$ "Trabalho e luz" nomeia um conjunto de dois sonetos contendo as respectivas versão séria e autoparódica do mesmo assunto e forma. Construído como peça de circunstância - parte das comemorações de inauguração, em 1883, do Liceu de Artes

28 Idem, p. 313.

29 Sobre o diálogo irônico que Bernardo Guimarães estabelece entre seus poemas, cf. SUSSEKIND, Flora. Romantismo com pé de cabra. In: Papéis colados. Rio de Janeiro: Editora da UFRJ, 1993, p. 142-3. 
e Ofícios de Ouro Preto,$-^{30}$ a versão séria louva o trabalho, a ciência e a fé, ressaltando, entre seus benefícios, a correção dos vícios e a renovação da cultura, o que permitiria alavancar o progresso de uma nação.

O poema satírico, no entanto, repete os vocábulos "trabalho" e "luz" em todos os versos, e mesmo por duas vezes como na primeira frase, num eco que forja o discurso como um arremedo da versão oficial e a desautoriza. Evidenciando a cristalização do discurso estabelecido em favor do trabalho e do progresso, esse tipo de ironia alveja o caráter mecânico da linguagem convencional e dela faz pastiche, sem necessariamente dizer o contrário do que afirma. ${ }^{31}$ Pressupondo a máxima de que o excesso de luz cega, a incansável reiteração dos termos-chave produz tanta ênfase e clareza que, na leitura, trava a sua compreensão e ofusca a cultura que desembocou na sacralização do trabalho, da racionalidade científica e do progresso.

Em outras sátiras, Bernardo Guimarães degenera o ócio em preguiça e nega os princípios cristãos distendidos em "Hino do prazer". Se aí o poeta exerce a arte com o objetivo de corrigir os costumes e traçar proselitismo religioso, posteriormente, contudo, critica tais propósitos e incorre em autoironia. A encenação da preguiça pode também mirar práticas literárias do tempo, que exaustivamente perpetuam convenções artísticas entronadas, desqualificadas quer tendo em vista a automação dessa perpetuação, quer considerando seu uso por qualquer parco talento. Com isso, a sátira do assunto pode resultar, conforme Vagner Camilo, ${ }^{32}$ de uma reflexão sobre os efeitos do mecenato e do apadrinhamento no circuito da produção literária, num país em que o alto número de analfabetos, a cultura do favor e da honra patrimonial e, em contrapartida, o desprezo pela cultura do dinheiro adquirido com a venda da mão de obra - aí incluída a empregada na produção da arte -, bem como a incipiência do mercado editorial, tudo isso contribuía para enfraquecer e atrelar o campo literário às razões do Estado imperial e do catolicismo, tendendo a restringir o exercício da literatura ao ócio estamental. Nesse cenário, a preguiça pode metaforizar, como em "O nariz perante os poetas", a falta de critérios na seleção de assuntos e de esmero na produção de escritores que, atentos à cooptação oficial, exercitavam a literatura como trampolim para a inserção social e o carreirismo político.

Em "Minha rede - canção" (1864), Bernardo veste a máscara do poeta inepto cuja

Cf. MAGALHÃES, Basílio. Bernardo Guimarães. Esboço biográfico. Rio de Janeiro: Typographia do Annuário do Brasil, s.d. 
produção se limita a desconexas linhas vagas, meros trouxe-mouxes. Estirado em sua rede e em diálogo com ela, o sujeito discursivo contempla o horizonte por uma janela esperando ler, no quadro natural, "doces sonhos de ventura e esperança”, numa suposição de que a contemplação da beleza natural alimentará o seu engenho e favorecerá a germinação de alguma ideia. Enquanto se entrega à indolência, o poeta concebe a rede como um mecanismo de transporte ao reino das vastas extensões do Universo. O movimento de ir e vir e seu correspondente efeito de entorpecimento levam-no a certa altura a observar uma nuvem cor-de-rosa. Transformando-a em objeto de culto, a voz enunciativa estabelece então um contraste entre a imensidão aérea e a amplitude marítima quando compara o deslizamento da nuvem pelo horizonte ao de uma prosaica piroga pelas águas do mar:

Nesse lânguido desleixo

Correr deixo

Minha vida descuidosa,

Contemplando ali defronte

No horizonte

Uma nuvem cor-de-rosa.

Pelo vão dessa janela,

Pura e bela,

Eu a vejo deslizar;

Pelo campo etéreo voga

Qual piroga

Cortando o cerúleo mar.

Linda nuvem, quem me dera

Pela esfera

Em teus ombros ir boiando,

E pairando sobre os montes,

Horizontes

Infinitos devassando.

No primeiro livro de poesias de Bernardo Guimarães, Cantos da solidão, o poema "Amor ideal" concebe a figura amorosa como uma essência aérea e vaporosa cuja 
companhia em um ambiente idílico poderia impelir o voo da imaginação poética pelas "margens do infinito" e garantir, assim, a inspiração de um "cismar puro e saudoso". Ainda nesse livro, a alma do poeta de "O devanear de um cético" entrega-se a um devaneio ocioso, esperando vagar "Além dos sóis, dos mundos, dos cometas/ Varando afouta a profundeza do espaço,/ Anelando entrever na imensidade/ A eterna fonte donde a luz emana...". Mas nas estrofes acima, de "Minha rede - canção", os signos da imensidão espacial como metáfora da busca pelo infinito conhecimento do mundo discutem satiricamente a codificação e as técnicas do estilo sublime. De acordo com seus princípios, o poeta, para apreender a infinitude do mundo e plasmar uma matéria grandiosa, deve amplificar a sua imaginação. O gesto de fazer coincidir a enunciação do poema com a observação do espaço infinito procura ilustrar o princípio de que a criação resulta de uma rica meditação sobre o mundo, vale dizer, de uma alma magnânima. Mas ao criar um poeta afeito à preguiça, Bernardo Guimarães figura inversamente uma consciência cuja apreensão poética do Universo se prende à extravagante nuvem de cor rosa, ainda mais incongruente na comparação com a piroga, a "rústica e primitiva embarcação indígena".33

Em outra passagem de "Minha rede - canção", o mandrião admite, não sem autocomiseração, a sua incapacidade para vagar pelo espaço infinito em que a nuvem se desloca e, com ela, dominar o seu engenho poético. De verso a verso, de estrofe a estrofe, "Minha rede - canção" acumula tagarelices, rebaixando como banalidade um princípio fundamental da estética romântica: a valorização da contemplação, da infinitude da imaginação e da reflexão poética esvai-se com a preguiça. A frustrada viagem da imaginação, que se revelou curta, troça, assim, do alto valor que certo romantismo destina ao gênio. Desclassificando a pretensão de qualidade de sua representação do mundo, apequena as dimensões do sublime. Contra ele, o poeta contrapõe a sua "divina" e pachorrenta "rede encantada", um símile da sátira que se lê.

Em análoga situação discursiva, as trinta quadras de "Hino à preguiça" (1883) dramatizam o diálogo mudo da persona satírica com a amada, desta vez encarnada na preguiça. Constituído de três partes, as seis estrofes introdutórias apresentam o perfil do sujeito satírico que, numa persistente indolência, roga a sua musa que o conduza a algum lugar aprazível, seja à sombra de um arvoredo próximo de uma fonte cujo som proporcione o sono, ou a um bosque cuja relva seja macia. Condicionando a 
escolha do lugar à sua facilidade de acesso e ao descanso, o anti-herói espera que, ao abrigo da natureza, a contemplação da paisagem desencadeie a gestação de uma "sã filosofia" ou de uma "reflexão grave e sublime". Para ilustrar a expectativa, propõe que, já instalado nesse lugar ameno, a observação da queda das folhas poderia gestar, por exemplo, a máxima de que "São as horas que aos poucos lá se vão". A associação entre queda das folhas e passagem do tempo encena a parvoíce poética de quem, produzindo platitude, avalia-a, no entanto, como matéria grandiosa. Ao sobrevalorizá-la, Bernardo Guimarães esvazia os pressupostos argumentativos do ócio, destruindo a determinação de que o idílio contemplativo seja uma das principais fontes da filosofia e da arte.

Na parte intermediária do poema em questão, as onze estrofes que a compõem procuram comprovar a tese de que o trabalho seja uma atividade ímproba e, em contrapartida, garantir que o ócio proporcione a tranquilidade da alma. Para tanto, revisa e reordena os pecados capitais, negativamente reduzindo-os a soberba, cobiça, avareza, inveja e fadiga do trabalho, mas positivamente alinhando a gula, a luxúria e a preguiça. Discreta, carinhosa e meiga, esta acalma o espírito e torna a vida aprazível. Assim ajuizando, o sujeito realiza uma cômica operação de retirada da preguiça do reino baixo dos vícios e uma comparação de igualdade ou de superioridade entre ela e as demais paixões.

As treze estrofes finais de "Hino à preguiça" criam um vínculo entre, de um lado, a sua santa musa e, de outro, temas, motivos e personagens do sistema estético do tempo. Para tanto, o sujeito rastreia a origem e a ascendência da preguiça para, em seguida, privilegiar seus produtos e efeitos. Nessa passagem, a leveza da sátira reverte-se de cinismo quando o falso mandrião remonta o nascimento de sua musa à terra americana:

Nasceste outrora em plaga americana

À luz de ardente sesta,

Junto de um manso arroio, que corria

À sombra da floresta.

Gentil cabocla de fagueiro rosto,

De índole indolente,

Sem dor te concebeu entre as delícias

De um sonho inconsciente. 
A informação de que a preguiça se originou na América aponta, inicialmente, para a evidência de que o habitat do bicho que leva seu nome são as matas tropicais desse continente. ${ }^{34}$ Extrapolando, no entanto, o caráter designativo do termo "preguiça", a persona satírica determina que ela seja filha de uma "gentil cabocla".

No século xviII, o termo "caboclo" nomeava oficialmente o indígena, o nativo e o natural. O século XIX mantém a sinonímia, acrescentando-lhe ainda o tapuia, o mestiço e o matuto. "Hino da cabocla" intitula a poesia de Junqueira Freire composta como uma síntese de sugestões poéticas fornecidas por "O canto do guerreiro" e "Marabá". Como neste poema, o hino de Freire compõe um eu lírico feminino indígena que, ao longo do poema, procura negar a suposta fragilidade de seu gênero e etnia: "Sou índia, sou virgem, sou linda, sou débil". Valendo-se do autoelogio da "bela de cabelos de ouro" de Gonçalves Dias, a guerreira de "Hino da cabocla" enaltece seus traços físicos e a sua disponibilidade para o amor, mas não sem louvar a sua máscula "inclinação" para o trabalho e a guerra, como o herói de "O canto do guerreiro", o que evidencia a adesão desses dois poetas à ideologia burguesa do trabalho.

Assim, por extensão, "cabocla" também designa, no século XIX, a literatura que canta os hábitos e costumes indígenas. Sílvio Romero refere-se à poesia indianista de Gonçalves Dias empregando o sintagma "poesia do caboclo". ${ }^{36}$ Forjando a nota para compor Bernardo Guimarães como um representante típico do suposto "espírito sertanejo" do país, Romero irrita-se com o culto romântico do estado de natureza, registrando, com alívio, que Bernardo se manteve "sempre avesso aos caboclismos exagerados". ${ }^{37}$

34 No século XIX, o debate sobre o bicho-preguiça foi travado por Peter Lund que, pesquisando desde 1835 as grutas de Lagoa Santa, descobriu na região fósseis gigantes do animal. Membro do IHGB desde 1839, o naturalista publicou os resultados de sua pesquisa ("Olhar sobre o mundo animal do Brasil") em Tratados de Ciências Naturais e Matemáticas da Sociedade Científica Real Dinamarquesa entre 1841 e 1846. Cf. HOLTEN, Birgitte; STERL, Michael. P. W. Lund e as grutas com osso em Lagoa Santa. Belo Horizonte: Editora UFMG, 2001.

Em seu Dicionário da língua portuguesa (1858), tomo I, Moraes da Silva incluiu o seguinte verbete: "Caboclo: de cor avermelhada, tirante a cobre; v. g. panela. Tapuia, gentio do Brasil". Cascudo, por sua vez, informa que um alvará de 1755, do el-rei d. José "mandava expulsar das vilas os que chamassem aos filhos indígenas de caboclos: 'Proíbo que os ditos meus vassalos casados com as índias ou seus descendentes sejam tratados com o nome de cabouçolos, ou outro semelhante que possa ser injurioso'. Macedo Soares registra a sinonímia tradicional de caboclo: caburé, cabo-verde, cabra, cafuz, curiboca, cariboca, mameluco, tapuia, matuto, restingueiro, mestiço". CASCUDO, Luís da Câmara. Dicionário do folclore brasileiro. 2. ed. Rio de Janeiro: Instituto Nacional do Livro/MEC, 1962.

36 ROMERO, Sílvio. História da literatura brasileira. Rio de Janeiro: Imago; Aracaju: Universidade Federal de Sergipe, 2001, t. 2, p. 812-3.

37 Idem, p. 805

452 C CUNHA, Cilaine Alves. Poema sem razão 
Num artigo sobre Iracema, de 1866, Machado de Assis, por sua vez, nega que os princípios da poesia brasileira do período se assentem exclusivamente no estudo da língua e na crônica indígena, pleiteando que este seja apenas um dos modos de exercer a literatura local. No mesmo passo, discorda de que essa fonte literária esteja esgotada, referindo-se ao indianismo da seguinte forma: "a poesia dos caboclos está completamente nobilitada: os rimadores das palavras já não podem conseguir o descrédito das ideias, que venceu com o autor de I-Juca Pirama, e acaba de vencer com o autor de Iracema".38

Ao remontar, assim, a filiação da preguiça à "gentil cabocla", "Hino à preguiça" mobiliza jocosamente o mito da origem da cultura local, creditando ao indianismo a responsabilidade pelo nascimento da primeira delas em solo americano. Em contrapartida, a preguiça produz a ação da cândida donzela pensativa e a fantasia ardente do vate que, ao entardecer, vaga pelo espaço. Ao imediato nascimento da preguiça em solo americano, as ramas do arvoredo paralisam-se, o rio aquieta-se, a fonte se esquece e a brisa adormece. Nesse momento, ela também cala o sabiá, que deixa "em meio o canto harmonioso", além de afrouxar as asas da águia quando ela, assaltada abruptamente de languidez, deixa cair a sua presa.

Diga-se assim que, sob a ótica do poema, a preguiça é filha e parricida do sistema estético do tempo, responsável pelo esgarçamento de algumas de suas tópicas, motivos e personagens: o idílio e o ócio romântico, a figura da incansável virgem que cisma e do gênio que dedica alto valor a sua imaginação; a obsessão do indianismo pelas origens; a valorização do sabiá por Gonçalves Dias; as asas de águia de Castro Alves; e a natureza idílica de tantos outros. A ossificação da linguagem artística ao longo do tempo metaforiza-se ainda no ato de a preguiça tudo apagar, retardando, ao final, o nascimento do sol e despertando o sono do poeta entediado.

Como no quiasmo estrutural próprio da ironia romântica, "Hino à preguiça" qualifica positivamente certas paixões que a cultura toma por pecado e, negativamente, princípios artísticos entronados. Para se estruturar, o poema leva em conta o objetivo maior da sátira romântica que, à maneira da sátira menipeia, procura desmontar e subverter valores e ideologias que organizam a cultura, sem procurar edificar. A posição de fala do eu satírico assemelha-se a um longo bocejar diante da cultura literária consagrada, concretizando a experiência de um leitor enfastiado quer com a estética romântica, quer com a poética neoclássica. $O$ procedimento crítico que

38 ASSIS, Machado de. Iracema. In: ALENCAR, José de. Iracema. Ed. crítica M. Cavalcante Proença. Rio de Janeiro: Livros Técnicos e Científicos; São Paulo: Edusp, 1979, p. 148. 
orienta o poema torna possível reconhecer que, em sua parte intermediária, esse cansaço favoreceu a relativização dos pecados capitais e o princípio da poética setecentista, ainda em voga no século XIX, regendo que a arte deva corrigir deleitando. Por volta de 188o, Bernardo Guimarães decreta a morte dos significados que orientavam a arte e o mundo ético, e a historicidade dos paradigmas culturais.

Cilaine Alves Cunha é professora de Literatura Brasileira na Universidade de São Paulo, autora de O belo e o disforme. Álvares de Azevedo e a ironia romântica (Fapesp/Edusp). 